\title{
TRTaKadeMi
}

ISSN 2149-9446 | Cilt 06 | Sayı 11 | Ocak 2021 |Büyük Veri

\section{Kovid-19 Salgını ve Mültecilere Yönelik Dijital Nefret Söylemi: Büyük Veri Perspektifinden Metin Madenciliği Tekniği ile Kullanıcı Kaynakıı İçeriklerin Analizi OĞUZ KUŞ}

\begin{abstract}
Öz
Bu çalışma Kovid-19 salgını sürecinde mültecilere yönelik dijital nefret söylemini ele almaktadır. Araştırma sürecinde büyük verinin düşünsel boyutunun sunmuş olduğu perspektif göz önünde bulundurulmuş, yenilikçi bir yaklaşım benimsenerek toplanan veriler analiz edilmiştir. Veri setini oluşturmak üzere YouTube'da uluslararası haber organizasyonlarının paylaşthğı Kovid-19 bağlamında mültecileri ele alan videoların altına yazılan kullanııı yorumları toplanmıştır. Analiz sürecinin sonucunda yorumların yüzde $29^{\prime}$ unun nefret söylemi içerdiği tespit edilmiştir. Nefret söylemi içeren yorum sayısı yüzde olarak az olduğu hâlde bu yorumlara gelen beğeniler toplam beğeni sayısının yüzde 49 'unu oluşturmaktadır. Kovid-19 salgını sürecinde mültecilere karşı dile getirilen dijital nefret söylemi geçmişte rastlanılan mültecilere yönelik nefret söylemi örüntüleri ile benzerlik göstermektedir. Nefret söylemi barındıran kullanıcı yorumları Hedef Ülkenin Dokunulmazlığı (yüzde 50), Amaca Yönelik Nefret Söylemi (yüzde 13), Kişisel Tercih ve Özelliklere Yönelik Nefret Söylemi (yüzde 17) ve Diğer (yüzde 20) kategorileri altnnda sınıflandırılmıştır. Hedef Ülkenin Dokunulmazlığı kategorisindeki yorumlar, nefret söylemi içeren yorumların almış olduğu toplam beğenilerin yüzde 62'sini almıştı. Diğer yandan, Hedef Ülkenin Dokunulmazlığı ve Amaca Yönelik Nefret Söylemi kategorileri genel ortalamanın üzerinde beğeni sayısına sahiptir. Çalışma kapsamında, nefret söylemi içeren yorumların dilsel yansıması bir ağ haritasıyla görselleştirilmiştir.
\end{abstract}

Anahtar Kelimeler: Kovid-19, Nefret Söylemi, Mülteciler, Büyük Veri, Metin Madenciliği

\section{Araştırma Makalesi}

Geliş Tarihi: 24.11.2020

Kabul Tarihi: 01.01.2021

ORCID ID: 0000-0002-2593-4980 DOI: 10.37679/trta.830736

E-mail:oguz.kus@istanbul.edu.tr 


\title{
COVID-19 Pandemic and Digital Hate-Speech Towards Refugees: Analysis of User-Generated Content from Big Data Perspective with Text Mining Technique OĞUZ KUŞ
}

\begin{abstract}
This study discusses the digital hate speech against refugees during the COVID-19 pandemic. The perspective provided by the ideological dimension of big data was considered in the research process and results were obtained by adopting an innovative approach. Comments, which were written by users to the YouTube videos about COVID-19 and refugees shared by international news organisations, were collected. As a result of the analysis process, it was found that 29 percent of comments contain hate speech. Even though the amount of hate speech is percentually low, they received 49 percent of the likes. The hate speech stated against refugees in the past and during the COVID-19 pandemic have similar patterns. Comments that contain hate speech were categorized as follows: Privilege of Destination Country (50 percent), Purpose-Oriented Hate Speech (13 percent), Hate Speech About Individual Choices and Personal Characteristics (17 percent) and Other (20 percent). Comments classified under Privilege of Destination Country received 62 percent of total likes of hate speech comments. On the other hand, average like count of Privilege of Destination Country and average like count of Purpose-Oriented Hate Speech categories are higher than the general average. Within the scope of the study, linguistic reflection of comments that contain hate speech were visualized with a network map.
\end{abstract}

Keywords: COVID-19, Hate Speech, Refugees, Big Data, Text Mining

Research Paper

Recieved: 24.11.2020

Accepted: 01.01.2021

ORCID ID: 0000-0002-2593-4980 DOI: 10.37679/trta.830736

E-mail: oguz.kus@istanbul.edu.tr 


\section{Giriş}

Çalışma kapsamında, Kovid-19 salgını sürecinde mültecilere yönelik dijital nefret söyleminin izi sürülmüştür. Farklı uluslararası haber organizasyonlarının Kovid-19 sürecinde mültecilerin durumuna değindiği YouTube videolarına yazılan kullanıcı yorumları Facepager (Jünger ve Keyling, 2020) ile toplanarak veri seti oluşturulmuştur. Verilerin analiz edilmesi sürecinde, içerik analizi yöntemi kullanılmış ve metin madenciliğinden faydalanılmıştır. Veri analizi sürecinde veriden etkin sonuçlar elde etmek üzere farklı araçlar bir arada kullanılmıştır. Verilerin ön işlemesi, ayıklanması ve algoritma için eğitim seti oluşturulması sürecinde Microsoft Excel ve Google Sheets, k-NN temelli bir sınıflandırma algoritması tasarlarken ve kelimelerin sayımını gerçekleştirirken Rapidminer Studio, eğitim setinin güvenilirliğini hesaplarken SPSS 21 ve ağ haritası tasarlarken Gephi 0.9.2 kullanılmıştır.

Büyük verinin sunmuş olduğu düşünsel dönüşüm ve buna bağlı olarak gelişen araştırma yaklaşımları toplumsal konuları farklı yönleriyle incelemeyi mümkün kılmaktadır. Çünkü Stephens-Davidowitz'in (2018) bahsettiği üzere yeni türde, dürüst ve farklı neden-sonuç ilişkileri kurmaya olanak tanıyan verilere ulaşmak mümkündür. Sosyal bilimler alanında gerçekleştirilen güncel araştırmalarda sosyal medya platformlarından toplanan verilerin kullanıldığına rastlanmaktadır. Sosyal medyadan toplanan veriler Bruns (2012) tarafindan zengin, erişilebilir ve tarafsız olarak betimlenmektedir. Bu tanımlardan yola çıkarak sosyal medyadan toplanan veriler ve büyük verinin düşünsel boyutu arasında bir örtüşme olduğu göze çarpmaktadır.

Dijital nefret söyleminin pek çok farklı türüne farklı bağlamlar dâhilinde sosyal medya platformlarında rastlamak mümkündür. Yeni medyada nefret söylemine maruz kalan gruplar arasında; göçmenler, sığınmacılar ve mülteciler sayılabilir. Çeşitli araştırmalar, sosyal medyada bu gruplara yönelik nefret söyleminin farklı boyutlarına yenilikçi analiz teknikleri ile ışık tutmuştur (Arcila Calderón v.d. 2020; Yun Shin, 2020; Jaki ve De Smedt, 2018; Kuş, 2016). Mevcut gündem göz önünde bulundurulduğunda, Kovid-19 bağlamında da yeni medya platformlarında ayrımcılık ve nefret içerikli gönderilerle karşılaşılmaktadır. Kovid-19 salgını bağlamında yeni medyada yaşlılara yönelik ayrımcılık (Türk, 2020; Tuna Uysal ve Tan Eren, 2020; Akgül; 2020) ve Çin ve Çinlilere yönelik ayrımcılıkla karşılaşıldığı (Ziems v.d. 2020; Awal vd. 2020) öncül çalışmalarda belirtilmiştir. Fakat Kovid-19 salgını sürecinde kırılgan bir grup olarak betimlenebilecek göçmenlere yönelik söylem hakkındaki çalışmalar Meciar'ın (2020) Türkiye'deki ve Çekya'daki çevrim içi gazeteler ve süreli yayınlardan seçtikleri makaleler üzerinden gerçekleştirdikleri araştırmayla sınırlı kalmıştır. Bu bağlamda, Kovid-19 salgını sürecinde yeni medyada mültecilere yönelik söylem hakkında çalışmalar yapmak önem taşımaktadır. Nefret söylemi dezavantajı 
grupları daha da kırılgan bir hâle getirdiğinden, bu çalışma YouTube'dan toplanmış olan kullanıcı yorumlarını nefret söylemi teorik zemininde ele almıştır. Ayrıca büyük verinin düşünsel boyutunun sunmuş olduğu perspektif göz önünde bulundurulmuş ve analiz sürecinde içerik analizi yöntemini merkezine alan yenilikçi bir yaklaşım benimsenerek detaylı sonuçlar elde edilmiştir.

Bu sebeple, çalışma çerçevesinde büyük veri için kavramsal bir çerçeve çizilmiş, dijital nefret söylemi ve mültecilere yönelik nefret söylemi konuları farklı boyutlarıyla ele alınmıştır. Kovid-19 salgını sürecinde ayrımcılık ve nefret söylemi üzerine gerçekleştirilen çalışmalara değinilmiştir. Son olarak Kovid-19 sürecinde mültecilere yönelik nefret söylemini ele alan bir araştırma gerçekleştirilmiştir.

\section{Büyük Verinin Teknik ve Düşünsel Boyutları Üzerine Bir Çerçeve}

Büyük veri, bireylerin gündelik hayatının farklı boyutlarını, sahip olduğu teknik ve düşünsel bileşenlerle dönüştüren ve zenginleştiren bir kavramdır. Büyük veri yenilikçi yöntemlerle depolanmakta ve disiplinlerarası bir perspektife sahip olan araştırma yaklaşımları ile bilgiye dönüştürülmektedir. Bu durum, bireylerin olay ve olgulara yönelik daha önce fark edemeyeceği bilgi örüntülerini keşfetme firsatı sunmaktadır.

Büyük verinin kavramsallaştırıldığı ilk zamanlarda bir firsat olmaktan uzak görüldüğünün, hatta bir 'sorun' olarak algılandığının alt çizilmelidir. Cox ve Ellsworth (1997: 1), "Görselleştirme bilgisayar sistemleri için ilginç bir zorluk ortaya çıkarmaktadır: Veri setleri genellikle fazlasıyla büyük, ana belleğin, yerel belleğin ve hatta uzak belleğin kapasitesini zorlamaktadır. Bu problemi büyük veri olarak adlandırmaktayız." ifadesini kullanmışlardır. Bu tanım büyük veriye doğrudan teknik özellikleri bağlamında yaklaşan bir yapıya da sahiptir. Panneerselvam ve diğerleri (2015: 3) ise büyük veriyi takip eden şekilde tanımlamışlardır:

Hızla değişim gösteren büyük ölçekli, fazlasıyla karmaşık ve veri analizleri için kullanılan sıradan donanım ve yazılımların yetkinlik sınırlarını aşan veri setlerinin yükselişidir.

Özetle, geleneksel yöntem ve araçlarla işlenmesi güç olan büyüklükteki verilerdir.

Mevcut tanımlar göz önünde bulundurulduğunda büyük verinin teknik olarak farklı bir doğaya sahip olduğu anlaşılmaktadır. Ayrıca, Narin ve diğerleri (2017, s. 218) "Büyük veri analizi yeni yöntemlerin geliştirilmesi ve öğrenilebilmesi için eğitime, verinin kayıtlanabilmesi için alt yapıya ve süreci yönetebilecek profesyonel iş gücüne ihtiyaç duymaktadır." önermesinde bulunmaktadır. Bu görüşler göz önünde bulundurulduğunda büyük verinin geleneksel veri setlerinin analiz sürecinin gerektirdiğinden daha yüksek bir teknolojik donanıma ihtiyaç duyduğu- 
nu belirtmek mümkündür. Buna ek olarak bu teknolojik donanımı, büyük veriyi analiz etmek üzere kullanabilecek teknik bilgiye sahip uzmanlara ihtiyaç duyulduğu da anlaşılmaktadır. Bu bağlamda, büyük verinin bir 'firsat' olarak algılanmaya başlamasında, büyük verinin sahip olduğu teknik bileşenlerin gerektirdiği teknolojik seviyeye ulaşılmasının ve büyük verinin analiz edilmesine yönelik "entelektüel bir birikimin" geliştirilmesinin önem taşıdığı ifade edilebilir.

Eaton ve diğerleri (2012: 5) büyük verinin üç özelliğinden bahsetmektedirler. Bunlar hacim, çeşitlilik ve hızdır. Hacim, verinin büyüklüğü ile ilgilidir. Geleneksel verilerin büyüklüğünü tanımlamak için kullanılan terimler, büyük verinin hacmini tanımlamak için yetersiz kalabilmektedir. Çeşitlilik, verideki çeşitliliğe işaret etmektedir. Çünkü büyük veri yapılandırılmış, yarı-yapılandırılmış ve yapılandırılmamış verileri; farklı formatları ve farklı amaçlarla toplanmış verileri içeren bir kümeye işaret etmektedir. Büyük verinin üçüncü bileşeni ise hızdır. Hız, verinin akış ve analiz hızına işaret etmektedir. Bu üç özelliğin, büyük verinin teknik boyutlarına işaret ettiğini belirtmek mümkündür. Fasel (2014) de benzer bileşenlerden bahsetmiş ve ek olarak "Yeni veri hızlı akmaktadır ve bu veriden değer üretmek için sahip olunan zaman aralığı hızla kısalmaktadır." önermesinde bulunmuştur.

Büyük verinin teknik özelliklerini, çalışma bağlamında veri kaynağı olarak sosyal medya kullanıldığından, sosyal medya platformlarında üretilen veri üzerinden örneklemek mümkündür. Örneğin, sosyal medya platformlarındaki yorumlar, yapılandırılmamış veri formlarıdır (Chi, 2020). Ayrıca, sosyal medya metin, video, fotoğraf gibi farklı formattaki verileri içermektedir. Bu durum, büyük verinin "çeşitlilik" bileşenine işaret etmektedir. Hacim noktasında geleneksel veri formlarını megabyte, gigabyte gibi ölçeklerle tanımlamak mümkündür. Fakat, büyük veri petabyte gibi, gigabyte'tan 1 milyon kat daha büyük olan, ölçeklerle tanımlanır. Facebook'un günde 4 petabyte veri ürettiği göz önünde bulundurulduğunda (Desjardins, 2019) sosyal medya platformlarında üretilen büyük verinin hacmine yönelik bir perspektif geliştirmek mümkündür. Sosyal medyada akan veriyle, büyük verinin hız bileşeni de örneklenebilir. Hammad ve diğerleri (2015) Twitter'da bir dakikada 98 binden fazla tweet atıldığına işaret etmektedir.

Yukarıda sosyal medya platformlarındaki veri üretimi üzerinden teknik özelliklerine değinilen büyük veri, bilgi üretmek noktasında yeni bir perspektif ve teknik olanaklar yaratmaktadır. Bu dönüşüm farklı bağlamlarda vuku bulan vakaları vakit kaybetmeden ve verimli bir şekilde analiz etmek için ihtiyaç duyulan veri miktarını ve teknik olanakları arttırdığı gibi olaylara yönelik yeni perspektifler geliştirmenin zeminini de hazırlamaktadır. Bu dönüşümün büyük verinin düşünsel boyutuna işaret ettiğini belirtmek mümkündür. Büyük verinin düşünsel boyutunu 
ele alırken Stephens-Davidowitz'in (2018) büyük verinin dört güçlü yönünü ifade ettiği önermeyi göz önünde bulundurmak mümkündür. Stephens-Davidowitz'e (2018) göre:

(1) Büyük veri eşi benzeri görülmemiş çeşitlilikte ve yeni türde veriler içerir. (2) Insanların ifade etmedikleri fikir ve soruları olmasına rağmen, bunları dijital dünya ile paylaşmaktan çekinmemektedirler (örneğin internet aramaları). Bu yönüyle, büyük verinin ikinci güvenilir özelliği ortaya konmaktadır; büyük veri samimi bir veri sunmaktadır. (3) Büyük veri alt kümelere odaklanmak için firsatlar sunmaktadır. (4) Büyük veri farklı neden sonuç ilişkisi kurma denemeleri gerçekleştirmeye izin vermektedir.

Büyük verinin düşünsel boyutlarına yönelik perspektifi geliştirmek, çalışmanın araştirma bölümü gerçekleştirilirken bu bileşenler göz önünde bulundurulduğundan önem taşımaktadır. Örneğin sosyal medya platformlarında paylaşılan büyük veri göz önünde bulundurulduğunda, araştırmacılar bireylerin belirli konulara yönelik tutumunu anlamak üzere daha önce mevcut olmayan özgün değişkenlere ulaşabilmektedir. Belirli bir konuda bildirilmiş görüşe ek olarak bu görüşe yönelik farklı kullanıcılar tarafindan gönderilen çeşitli etkileşim düzeyleri de elde edilebilmektedir. Geleneksel yöntemlerle toplanan veride bir katılımcının spesifik bir konuda belirtmiş olduğu fikri öğrenmek mümkün olsa dahi bu fikir hakkında farklı kişilerin ne düşündüğü hakkında veri toplamak büyük bir zaman kaynağı gerektirmektedir. Fakat büyük verideki, etkileşim gibi, değişkenler yeni türde verilere ve yeni iç görülerin elde edilebilme imkânına işaret etmektedir.

Stephens-Davidowitz'in değindiği üzere büyük veri samimidir. Bu durumu sosyal ağ tartışmalarında gözlemlemek mümkündür. Çünkü kullanıcılar güncel olaylar hakkında fikirlerini ifade etmektedir veya başka kullanıcılarla doğrudan etkileşime geçebilme imkânına sahip olmaktadır. Samimiyet düzeyinin artş̧ında anonim olma hâlinin etkisi olsa da büyük veri spesifik bir konuyu güncelliğini yitirmeden farklı boyutlarıyla anlamak üzere imkânlar sunmaktadır.

Stephens-Davidowitz büyük verinin alt-kümelere odaklanmaya ve farklı neden sonuç ilişkileri kurmayı denemeye imkân tanıdığının altını çizmektedir. Büyük verinin düşünsel boyutuna yönelik bu iki bileşenin birbirleriyle ilintili olduğunu belirtmek mümkündür. Örneğin Twitter'daki geo-location bilgisi kullanılarak bir ülkenin hangi bölgesinde, hangi türde nefret söylemi türlerinin mevcut olduğunu görselleştiren araştırmalar (Chaudhry, 2015; Musto v.d., 2016) mevcuttur. Büyük verinin mevcut olmadığı bir düzlemde, geleneksel yöntem ve veri tipleriyle bu kadar detaylı bölgesel alt kırılımlara erişmenin güç olacağını ifade etmek mümkündür. Tespitlere yönelik alt kırılımların artması ise doğal bir sonuç olarak daha 
detaylı ve yeni türde neden sonuç ilişkileri kurmaya olanak tanımaktadır.

Büyük ölçekli veri setlerinin metin madenciliği ile analiz edilmesine veya sosyal ağ analizlerini içeren çalışmalara sosyal bilimler alanında da rastlanmaktadır. Buna ek olarak iletişim alanında gerçekleştirilen çalışmalarda sosyal ağlardan toplanan verilerle gerçekleştirilen pek çok araştırma göze çarpmaktadır. Bu bağlamda Bruns'ın (2012:1328) önermelerini göz önünde bulundurmak önemlidir:

Çevrim içi sosyal ağlar araştırmacılar arasında merak uyandırmaktadır çünkü, çoğu bölümünde zengin, erişilebilir ve belirgin bir şekilde tarafsız veri bulunmaktadır. Bir araştırmacı için Twitter'daki kamuya açık uzun bir tartışmada kimin kime hangi şartlar altında ne söylediğini saptamak; benzeri bir çevrim dışı tartışma için anlaşılır ve yanlışsız bir veri üretmekten daha kolaydır.

Bruns'ın bu görüşünün, büyük verinin düşünsel boyutlarıyla da örtüştüğünü not etmek mümkündür. Ayrıca, iletişim araştırmacılarının odağındaki farklı konuların sosyal ağlarda da bir yansımasının olması veriye ulaşmak noktasında sosyal ağları değerli kılmaktadır.

Büyük verinin analiz edilme sürecine değinmek de önem taşımaktadır. Büyük veri analizlerinin gerçekleştirilebilmesi için yenilikçi bir perspektif gerekmektedir. Bu perspektifin örneklemden ziyade evrenin bütününe yönelik bir veri toplama eğilimi izlediği ifade edilmelidir. Analiz süreci kimi zaman geleneksel veri analizi tekniklerini içeriyor olsa da makinelerin öğrenmesi, veri madenciliği, programlama gibi disiplinlerarası bir yaklaşımı da içermektedir. Büyük verinin bilgiye dönüştürülmesi hususunda veri bilimi kavramı önemli bir açılım sağlamaktadır. Akdeniz'e göre (akt. Sütcü ve Aytekin, 2018: 81) veri bilimi veriden elde edilen bilginin genelleştirilebilir çıkarımlarının araştırılmasıdır ve farklı bileşenlerle harmanlanan ardışık bir sürece sahiptir: (1) ilgilenen soruyu tanımla, (2) Veriyi elde et, (3) Veriyi ayıkla, (4) Veriyi kontrol et, (5) İstatistiksel modeller uydur, (6) Sonuçları duyur, (7) Analizi yeniden oluşturabilecek şekilde yap bu sürecin aşamalarıdır.

Büyük veriye yönelik yukarıda bahsedilen kavramsal çerçeve göz önünde bulundurulduğunda, yenilikçi araştirma perspektifleri benimsenerek analiz edilen büyük ölçekli verilerin sosyal bilimlerin farklı alanlarına katkı sağlama potansiyeli taşıdığı yorumunu yapmak mümkün hâle gelmektedir. Ayrıca, sosyal medyadan toplanan verilerin etkin ve özgün sonuçlara ulaşmak noktasında fayda sağlama potansiyeli bulunduğu açıktır. Geleneksel yaklaşımlarla toplanması zor olan verinin toplanabilmesi ve bu büyüklükteki veri setlerinin otomatik veya yarı-otomatik bir şekilde analiz edilmesi süreçlerinin araştırmalara dâhil edilmesi de güncel konular hakkında yeni perspektiflerin oluşturulmasına olanak tanımaktadır. Diğer 
yandan, büyük veri ve beraberinde getirdiği bakış açısının içerik analizi, söylem analizi veya metinlerdeki örüntülerin keşfi konusunda sosyal bilimler alanında çaIışmalar yürüten araştırmacılara yeni imkânlar sunabileceği gözlemlenmektedir. Bu durum, bu çalışmada da bir dijital platformdan veri toplanmış olması ve bu veri setinin yenilikçi bir yaklaşımla analiz edilmesi sebebiyle önem arz etmektedir.

\section{Nefret Söylemine Yönelik Kavramsal Bir Çerçeve, Mültecilere Yönelik Dijital Nefret Söylemi ve Kovid-19 Bağlamındaki Gelişmeler}

Araştırmanın önceki bölümünde değinildiği üzere sosyal ağlardan toplanan büyük ölçekli veri, yenilikçi yaklaşımlar kullanılarak analiz edilmekte, söylem analizi ve içerik analizi içeren çalışmalar gerçekleştirilmektedir. Sosyal ağlardan toplanan büyük ölçekli veri, yenilikçi araç ve yaklaşımlarla analiz edilerek farklı bağlamlarda ortaya çıkan nefret söylemi üzerine odaklanan çalışmalar da bulunmaktadır. Bu çalışma bağlamında Kovid-19 pandemisi çerçevesinde mülteci algısı ele alınıp kullanıcı kaynaklı içerikler aracılığı ile ifade edilen ve dijital nefret söylemi olarak tanımlanabilecek olan içerikler kategorize edileceğinden nefret söyleminin kavramsal çerçevesini belirlemek önem taşımaktadır. Parekh (2006: 214) nefret söylemini şu şekilde tanımlamaktadır:

Nefret söylemi belirli bir özellik veya özellikler bütünü sebebiyle farklılaşan bir grup bireye karşı düşmanlığın dile getirilmesi, savunulması, teşvik edilmesi veya kışkırtılmasıdır. Nefret; saygının yokluğu veya pozitif saygısızlık, hoşlanmama, onaylamama veya başkalarına karşı küçültücü bakış açısıyla aynı değildir. Nefret; düşmanlık, reddediş, zarar verme ve yok etme isteği, hedef grubu saf dışı bırakma, sessizleştirme veya pasifleştirme arzusu güder.

Bu bağlamda nefret söyleminin farklılıkları, zarara yol açacak şekilde yadsıma eğilimi söz konusudur. Bu noktada, nefret söylemi konsensüse ulaşmayı hedefleyen bir ifade biçiminden ziyade, belirli bir gruba yöneltilmiş baskın olma, onu pasifize etme ve ona yönelik sözel ya da fiziksel şiddeti teşvik etme hâline işaret etmektedir.

Diğer yandan, Weber (2009: 3) nefret söyleminin biçimi ve kurbanlarına yönelik detaylar içeren tanımında, Avrupa Konseyinin Bakanlar Komitesi kararını alıntılayarak nefret söylemini aşağıdaki şekilde tanımlamıştır:

Irkçı nefreti, yabancı düşmanlığını, Yahudi düşmanlığını veya azınlıklara, göçmenlere ve göçmen kökenli insanlara yönelik saldırgan ulusalcılık ve etnik merkezcilik, ayrımcılık ve düşmanlık şeklinde ifadesini bulan, dinsel hoşgörüsüzlük dâhil olmak üzere hoşgörüsüzlüğe dayalı başka nefret biçimlerini yayan, kışkırtan, teşvik eden veya meşrulaştıran her türlü ifade biçimi 
Weber'in pek çok farklı araştırmada kullanılan tanımından yola çıkarak dezavantajlı grupların, değişen tematik bağlamlarda nefret söyleminin odağında olduğunu belirtmek mümkündür. Ayrıca, Weber ve Parekh'in öne sürmüş olduğu nefret söylemi tanımlarının birlikte göz önünde bulundurulması önemlidir. Çünkü Parekh'in tanımı nefret söyleminin arkasındaki motivasyona yönelik detaylar sunarken Weber ise bu nefretin yöneldiği gruplar hakkında fikir sahibi olunmasına olanak tanımaktadır. Her iki nefret söylemi tanımı da nefret söyleminin, hedef hâline gelen grupların yaşamını zorlaştırdığına ve toplumsal eşitsizliklere zemin hazırladığına yönelik bir çıkarımda bulunmayı olanaklı kılmaktadır.

Nefret söylemi sosyal medyada da sıklıkla rastlanılan bir pratiktir. Yukarıda bahsedilen nefret söylemi bileşenlerine yeni medya platformlarında paylaşılan içeriklerde de farklı bağlamlar dâhilinde rastlanmaktadır. Yeni medyanın etkileşime dayanan doğası, nefret söyleminin ortaya çıkmasına ve yayılmasına da olanak tanımaktadır. Binark'ın Lister ve diğerlerinden aktardığına göre (2010: 26), yeni medyayı geleneksel medyadan farklılaştıran dijitallik, etkileşimsellik, hipermetinsellik, yayılım ve sanallık ve multimedya biçemselliği gibi özellikler sebebiyle yeni medyada nefret söylemi geleneksel medyaya göre daha yaygın, daha kolay erişilebilir, daha kolay üretilebilir ve sonuçta daha sıradan kılınmaktadır.

Dijital nefret söylemini doğrudan ve dolaylı olmak üzere iki biçimde ele almak mümkündür. Kuş (2016: 100) nefret söylemi içeren bir içeriğin sosyal ağlarda üretilmesini, nefret söylemi içeren yorumların paylaşılmasını doğrudan nefret söylemi olarak isimlendirirken; sosyal ağlarda paylaşılan ve nefret söylemi içeren bir içeriğin beğenilmesi veya tekrar paylaşılmasını dolaylı nefret söylemi olarak tanımlamak gerektiğini ifade etmektedir. Çalışmada, sosyal ağ algoritmalarının beğenilen ve tekrar paylaşılan, diğer bir deyişle etkileşim alan, gönderilerin görünür olmasına olanak tanıdığı ve dolayısıyla bunun da nefret söylemini beslediği ifade edilmektedir.

Mültecilere karşı yeni medya platformlarında üretilen dijital nefret söyleminde düşmanlığın açıkça dile getirilmesi, etnik veya din merkezli hoşgörüsüzlük ve saldırgan bir dile sıklıkla rastlanmaktadır. Bu çalışmaların bulguları, bir yönüyle Weber ve Parekh'in öne sürdüğü bileşenleri içermektedir ve nefret söyleminin motivasyonu, dile getirilme biçimi ve hangi bağlamda geliştiği noktasında yorum yapmaya olanak tanımaktadır. Arcila Calderón ve diğerleri (2020), Twitter'dan yüksek miktarda veri toplayarak gerçekleştirmiş oldukları çalışmada, göçmenlere yönelik nefret söylemi içerdiğini tespit ettikleri tweetlerde küfürlü konuşma, yanIış/şüpheli bilgi, ironi, aşağılama, öfke, tehdit ve şiddete teşviğin yaygın bir şekilde kullanıldığını tespit etmişlerdir. Jaki ve De Smedt (2018) 100'den fazla Twitter 
kullanıcısından 50 binden fazla nefret içerikli tweet toplamışlardır. Araştırmacılar, tweetlerin çoğunun göçmenleri tasvir ederken nefret dili içerdiğini ve önemli bir kısmının yanıltıcı ve dehümanize edici olduğunun altını çizmektedirler. Yun Shin (2020), Yemenli mültecilere yönelik haberlere yazılmış olan kullanıcı yorumlarını metin madenciliği ile analiz ettiği çalışmasında mültecilere yönelik küçük düşürücü ve negatif söylemler üretildiğini belirtmektedir. Yun Shin'e göre kullanıcı yorumları steretotipler, küçük düşürücü şakalar, negatif bilgiyi kabul eden, isim takan ve dehümanize eden nefret ve ayrımcılık içeren ifadeler barındırmaktadır.

Bu noktadan hareketle mültecilerin dijital nefret söyleminin hedefindeki dezavantajlı gruplardan birisi olduğunu belirtmek mümkündür. Diğer yandan nefret söyleminin yeni medya platformlarında üretilmesi olarak tanımlanabilecek bu durum, dijital nefret söyleminin kendine has dinamikleri olduğunu da göstermektedir. Yeni medya platformlarındaki etkileşim dinamiği nefret söyleminin üretilmesini ve yayılmasını olanaklı kılarken platformlardaki beğenme veya oylama gibi fonksiyonların nefret söylemi üreten kullanıcılar arasında birbirini onaylama mekanizması gibi çalışabileceği algısını kuvvetlendirmektedir. Bu durum ortaya bir nefret sarmalı çıkarma potansiyeli taşıdığı gibi nefret söyleminin daha tehlikeli boyutlara ulaşması ihtimalini de kuvvetlendirmektedir. Çünkü, özellikle sosyal ağlarda, algoritmaların kullanıcılara daha önce etkileşime girdikleri içeriklerin benzeri içerikleri gösterme eğilimi de göz önünde bulundurulması gereken bir parametredir. Algoritmalar genellikle bireylerin geçmiş davranışlarından öğrenerek onlara bu bağlamda ilgili içerikler sunmaktadır. Bu kişiselleştirme algoritmaları bir çeşit görünmez oto-propaganda gibi işlemektedir (Pariser, 2011: 15). Böylece sosyal medya kişinin kendi yansımasını gördüğü bir forma dönüşmekte ve nefret söylemi ile mücadele etmek daha zor bir hâl almaktadır.

Diğer yandan, nefret söyleminin kurbanları, gündemdeki farklı konuların etkisiyle değişebilmektedir. Bu durum, belirli dönemlerde nefret söyleminin yoğunlaşmasına ya da bireysel davranışların belirli bir gruba mal edilerek nefret söylemi üretilmesine sebep olabilmektedir. Bu noktadan hareketle Kovid-19 pandemisinin de küresel ölçekte toplumsal etkiler yarattğını belirtmek mümkündür. Bu sebeple çalışmada, Kovid-19 pandemisinin nefret söylemi ve ayrımcılık konularına etkilerinin neler olabileceğini tartışmak elzemdir. Bu bağlamda farklı çalışmalar, yaşlıların ve Çinlilerin dijital nefret söyleminin hedefi hâline geldiğine işaret etmektedir.

Sosyal medyada paylaşılan görüntülerde yaşlılar bir gösteri malzemesi hâline getirilmiş ve yaşlılara yönelik rencide edici davranışlar gerçekleştirilmiştir (Türk, 2020: 42). Tuna Uysal ve Tan Eren (2020: 1159), gerçekleştirmiş oldukları araştır- 
mada Twitter'da gerçekleştirilen paylaşımlarda yaşlıların ayrımcılığa maruz kaldığını ifade etmişlerdir. Araştırmacılar "yapılan paylaşımlar çerçevesinde yaşılırla alay edildiği, küçümsendiği, aşağılandığı, hakaret edildiği, şikâyet edildiği, nefret ve tehdit söylemlerine maruz kaldıklarının" altını çizmişlerdir. Akgül (2020: 76) de gerçekleştirmiş olduğu çalışmada Ekşi Sözlük'teki '21 Mart 202065 yaş üstüne sokağa çıkma yasağı' başlığına gönderilen kullanıcı girilerini incelemiş, girilerde nefret içeren çok sayıda küfür, hakaret, aşağılama ve ötekileştirme içeriği tespit etmiştir. Araştırma bulgularında yaşlıların toplumsal üretim zincirinin dışına çıkmış, hiçbir faydası olmayan, sorunların önemli bir kısmının kaynağı şeklinde görüldüğüne yer verilmiştir. Bahsedilen araşttrmalar göz önünde bulundurulduğunda, Kovid-19 bağlamında toplumdaki belirli bir gruba yönelik nefreti körükleyici ve bu grubu yok sayan bir yaklaşımın yeni medya platformlarında dile getirildiği gözlemlenmektedir.

Diğer yandan, salgındaki ilk vakaların raporlandığı Çin'e ve Çinlilere yönelik ırkçı yaklaşımlara rastlandığına da dikkat çekilmektedir. Sivil toplum örgütleri Kovid-19 salgınıyla bağlantılı olarak ırkçı/yabancı düşmanı ayrımcılık ve şiddette artış olduğunu, Asyalılara ve özellikle Çinlilere yönelik saldırılarda endişe verici bir artı̧̧ olduğunu dile getirmişlerdir (Human Rights Watch'tan aktaran Peters, 2020). Ayrıca Çin ve Çinlileri hedef alan nefret söylemlerinin de yeni medya platformlarında dolaşıma girdiği görülmektedir. Tunçer (2020: 80) Ekşi Sözlük’te Çinli algısına yönelik gerçekleştirmiş olduğu çalışma kapsamında, Çinli algısını takip eden şekilde ifade etmektedir: "Çin'deki durum, insani destek, hangi önlemlerle salgının önüne geçilebileceğinden ziyade pandeminin 'şeytani' bir güç atfedilen Çin'in merkezinde olduğu komplo teorileriyle ilişkilendirildiği, teorilerin milliyetçi-dini referanslarla desteklendiği, Çin kültürünün yerilerek Çinlilerin ötekileştirildiği görülmektedir." Bu bulgulardan hareketle Kovid-19 bağlamında sadece dezavantajı grupların değil, bir ülke ve onun üyelerine yönelik daha geniş ölçekli bir grubu hedef alan ötekileştirme pratiğinin ortaya çıktı̆ı yorumunu yapmak da mümkün hâle gelmektedir. Ayrıca bu durum, güncel gelişmelerin farklı grupları nefret söyleminin kurbanı hâline getirme potansiyeli taşıdığına işaret etmektedir.

Uluslararası ölçekte de pandemi bağlamında Çin'e ve Çinlilere yönelik nefret söylemini ele alan çalışmalar mevcuttur. Ziems ve diğerleri (2020) Kovid-19'un sosyal medyada Çinlilere ve Asyalılara yönelik ırkçılık, nefret ve yabancı düşmanlığını harekete geçirdiğini belirtmektedir. Ayrıca nefret söylemi üreten ve buna karşı çıkan kullanıcıların etkileşim içinde olduğu ve nefret içeriğine maruz kalan bir bileşenin, sonrasında nefret dolu olma eğilimi gösterdiği çalışmanın bulguları arasındadır. Bu bulgular, dijital nefret söyleminin yayılma kolaylığına ve etki alanının 
nasıl genişleyebileceğine yönelik bir örnek de oluşturmaktadır. Benzer şekilde Awal ve diğerleri de (2020) Kovid-19 salgını sürecinde antisosyal davranışları ele aldıkları çalışmalarında Twitter'daki retweet işlevinin antisosyal içeriğin yayılması konusunda önem taşıdığını belirtmektedir. Araştırmacılar, belirli bir tarihteki antisosyal içerikteki yükselişin sebebini incelediklerinde, antisosyal içeriklerin çoğunun Çinlilere yönelik ayrımcı bir dile sahip bir tweetin tekrar paylaşımı olduğunu belirtmişlerdir. Bu durum, dolaylı nefret söyleminin de doğrudan nefret söylemi kadar tehlikeli olabileceği yorumunu yapmayı mümkün kılmakla birlikte, dijital nefret söylemi çalışmalarında etkileşim miktarı ve biçimlerinin araştırmalara dâhil edilmesi gereken bir değişken olduğuna da işaret etmektedir.

Pandemi şartları dezavantajlı grupların karşılaşmış oldukları zorlukları arttırmaktadır. Mülteciler ve göçmenler de hayat şartları bağlamında bu zorluklarla karşılaşan gruplar arasındadır. Guadagno'ya (2020: 4) göre dil engeli, sosyal mesafe sağlayamama, hijyen materyallerine erişimde zorluk, çalışırken sınırlı koruyucu ekipmana sahip olmaları göçmenlerin Kovid-19 ile temasa geçme ihtimalini arttırmaktadır. Ayrıca göçmenleri kırılgan kılan farklı faktörler Kovid-19 sürecinde göçmenlerin uygun hizmetlere erişememe, yaşadıkları semptomların çok güçlü olması, psikolojik olarak etkilenme, geçim ve gelir güvensizliği ihtimalini arttırmaktadır.

Kovid-19 salgını bağlamında göçmenler, mülteciler ve sığınmacıların nefret söyleminin hedefi hâline gelip gelmediğine, nefretin söyleminin sebeplerine ve yayılma biçimine yönelik yeterli miktarda çalışma bulunmamaktadır. Bu noktada Kovid-19 salgını bağlamında dezavantajlı bir grup olan mültecilere yönelik algının ve dile getirilen nefret söyleminin kapsam ve boyutunu tartışmak önem taşımaktadır. Çünkü söylem, gerçeklik inşasında ve davranışların oluşumunda önem arz etmektedir. Bu noktada salgın şartlarında var olan mülteci algısı ve üretilen söylemin, mültecilerin salgından korunması ve kırılganlıklarının engellenmesi noktasında önem arz ettiğini belirtmek mümkündür.

\section{Amaç ve Yöntem}

Bu başlık altında çalışmanın amacı ifade edilmiş ve araştırmanın yöntemi hakkında bilgi aktarılmıştır.

\section{1. Amaç}

Çalışmanın birincil amacı Kovid-19 salgını bağlamında mültecilere yönelik nefret söylemi içeriği taşıyan kullanıcı kaynaklı içerikleri tematik olarak kategorize etmek ve kullanıcıların dijital nefret söylemi üretimini tetikleme potansiyeli taşıyan 
sebeplere ışık tutmaktır. Öncül araştırmalar ve doğrudan/dolaylı nefret söylemi hususunda daha önceki bölümlerde değinilen önermeler dijital platformlardaki etkileşimin dijital nefret söyleminin üretim hızını ve görünürlüğünü arttıracağına işaret etmektedir. Bu noktadan hareketle, tematik olarak kategorize edilen kullanıcı kaynaklı dijital nefret söylemi içeren içeriklerin beğeni miktarı ve ortalamalarının karşılaştırılması amaçlanmaktadır. Son olarak, Kovid-19 salgını bağlamında mültecilere yönelik nefret söylemindeki dilsel kullanım ağ haritasıyla görselleştirilecektir. Çalışma, Kovid-19 bağlamında mültecilere yönelik üretilen dijital nefret söylemi ile ne şekilde mücadele edilebileceği hakkında çözüm önerileri sunmayı hedeflemektedir. Belirlenen amaç doğrultusunda üç adet araşttrma sorusu öne sürülmüştür:

A.S. 1: Kovid-19 salgını bağlamında mültecilere yönelik nefret söylemi içeriği taşıyan kullanıc kaynaklı içeriklerin tematik dağılımı nedir?

A.S. 2: Kovid-19 salgını bağlamında mültecilere yönelik nefret söylemi içeriği taşıyan kullanıcı kaynaklı içeriklerin beğeni miktarı nedir?

A.S. 3: Kovid-19 salgını bağlamında mültecilere yönelik nefret söylemi içeriği taşıyan kullanıcı kaynaklı içeriklerin dilsel yansıması nedir?

\section{2. Yöntem}

Betimsel bir perspektifi benimsemiş olan bu çalışma kapsamında araştırma sorularına cevap vermek üzere önceki bölümlerde değinilen büyük verinin düşünsel boyuttaki özellikleri göz önünde bulundurularak sosyal medyadan veri toplanmış; veri analizi sürecinde içerik analizi yöntemi kullanılmış ve bu süreçte metin madenciliğinden faydalanılmıştır.

Araştırma kapsamında, metin madenciliğine Witten'in (2005, s. 314) öne sürmüş olduğu perspektiften yaklaşılmaktadır:

Metin madenciliği doğal dil metinlerinden anlamlı bilgiler elde etmeyi deneyen yeni bir alandır. En geniş hâliyle belli bir amaç doğrultusunda metinleri analiz etme ve bilgi elde etme süreci olarak karakterize edilebilir. [...] başarı kısmi olsa bile!

İçerik analizi yöntemi çerçevesinde metin madenciliğinden faydalanırken Yan ve diğerlerinin (2014) geliştirmiş olduğu yarı-otomatik içerik analizi yaklaşımı benimsenmiştir. Bu bağlamda Şekil 1'deki aşamalar göz önünde bulundurulmuştur. Insan kodlaması aşamasında Atlas.ti yerine Microsoft Excel kullanılmıştır. 
Şekil 1. Yan Ve Diğerlerinin Yarı Otomatik İçerik Analizi Şeması

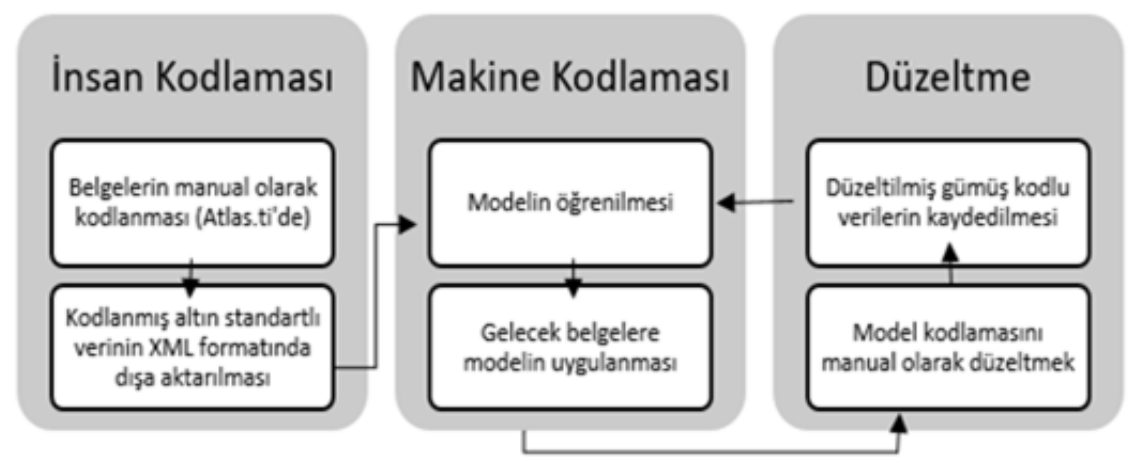

Yan, J. L. S. McCracken, N. ve Crowston, K. (2014). Semi-Automatic Content Analysis of Qualitative Data. In iConference 2014 Proceedings (p. 1128-1132)

\subsection{Veri Toplama}

Çalışma, Kovid-19 salgını sürecinde mültecilere yönelik nefret söylemine ışık tutmayı hedeflediğinden, veri seti YouTube'daki kullanıcı yorumlarının ve bu yorumlara gelen beğenilerin toplanmasıyla oluşturulmuştur. Veri toplanırken YouTube'da "refugee covid19" sorgusu yapılmıştır. Bölgesel çeşitlilik göz önünde bulundurularak, İngilizce haber yayımlayan uluslararası haber organizasyonları tarafindan paylaşılmış olan videolara gelen kullanıcı yorumları toplanarak veri seti oluşturulmuştur. Uluslararası haber organizasyonlarının paylaştığı videolara yazılan kullanıcı yorumlarının göz önünde bulundurulmasının iki sebebi bulunmaktadır. Uluslararası haber organizasyonlarının, kamuoyunu habercilik kuralları çerçevesinde bilgilendirme hedefiyle hareket ettiği düşünülmektedir. Böylece, YouTube'da benzer konuda video içerik üreten bağımsız kullanıcılardan farklılaşmaktadır. Bu durum, içeriklerinin daha tarafsı olacağı yorumunu yapmayı mümkün kılmaktadır. Diğer gerekçe ise uluslararası haber organizasyonlarının hedef kitlesi çeşitlilik barındırmaktadır. Böylece, bu video haberler farklı fikirlere sahip olan izleyicilerin buluşma noktası işlevi görmektedir.

Veri toplama sürecinde Facepager (Jünger ve Keyling, 2020) kullanılmıştır. Veri toplama sürecinde 510 kullanıcı yorumu ve 3636 kullanıc etkileşimi toplanmıştrr. Veri toplama işlemi 13.11.2020 tarihinde gerçekleştirilmiş ve sadece birincil yorumlar göz önünde bulundurulmuştur. Yorumlara cevap olarak yazılan ikincil yorumlar araştırmanın dışında tutulmuştur. Yorumların toplandığı haber videolarının konusu ve haber organizasyonunun konumu Tablo 1'de listelenmiştir. 
Tablo 1. Yorumların Toplandığı Video Haberler ve Haber Siteleri Hakkında Bilgi

\begin{tabular}{|l|l|}
\hline Video Konusu & Haber Organizasyonunun Konumu \\
\hline $\begin{array}{l}\text { Pandemi sürecinde mülteciler için duyulan endişe } \\
\text { ve yardım organizasyonlarının fikirleri ve çalışmaları } \\
\text { aktarılmaktadır. }\end{array}$ & Orta Doğu merkezli \\
\hline $\begin{array}{l}\text { Pandemi sırasında Avrupa'daki bir liman kentinde } \\
\text { kalan mültecilerin durumu aktarılmaktadır. }\end{array}$ & Orta Doğu merkezli \\
\hline $\begin{array}{l}\text { Sertleşen hava şartları ve Kovid-19 bağlamında Rohin- } \\
\text { gya mültecilerinin durumu anlatılmaktadır. }\end{array}$ & Orta Doğu merkezli \\
\hline $\begin{array}{l}\text { Mültecilerin pandemi sürecinde nasıl bir tehlike altın- } \\
\text { da olduğu uzman görüşleriyle aktarılmaktadır. }\end{array}$ & Kuzey Amerika merkezli \\
\hline $\begin{array}{l}\text { Diğer konuların yanı sıra AB ülkelerinin Kovid-19 bağ- } \\
\text { lamında mültecilere yönelik tutumunu da tartş̧an bir } \\
\text { haber. }\end{array}$ & Orta Doğu merkezli \\
\hline $\begin{array}{l}\text { Bir mülteci kampında yerel yönetim kurumlarının hızlı } \\
\text { davranarak mültecileri Kovid-19'dan nasıl koruduğunu } \\
\text { anlatan bir haber. }\end{array}$ & Kuzey Amerika merkezli \\
\hline $\begin{array}{l}\text { Diğer konuların yanı sıra AB ülkelerinin Kovid-19 bağ- } \\
\text { lamında mültecilere yönelik tutumunu da tartş̧an bir } \\
\text { haber. }\end{array}$ & Orta Doğu merkezli \\
\hline $\begin{array}{l}\text { Kovid-19 ve mülteciler hakkında, bir mülteci ve uzma- } \\
\text { nın da dâhil olduğu bir haber. }\end{array}$ & Kuzey Amerika merkezli \\
\hline Kovid-19 ve mülteciler bağlamında geniş bir haber. & Orta Doğu merkezli \\
\hline $\begin{array}{l}\text { Pandemi sürecinde Suriyeli mültecilerin durumuna } \\
\text { yönelik bir haber. }\end{array}$ & Kuzey Amerika merkezli \\
\hline $\begin{array}{l}\text { Pandemi sürecinde Rohingya mültecileri hakkında bir } \\
\text { haber. }\end{array}$ & Orta Doğu merkezli \\
\hline $\begin{array}{l}\text { Salgın sürecinde ülkesine geri dönen mülteciler hak- } \\
\text { kında bir haber. }\end{array}$ & Orta Doğu merkezli \\
\hline Rohingya mültecileri ve salgın hakkında bir haber. & Asya merkezli \\
\hline $\begin{array}{l}\text { Avrupa'daki bir kampta kalan mültecilerin durumu } \\
\text { anlatılmaktadır. }\end{array}$ & Avrupa merkezli \\
\hline
\end{tabular}

Toplanan 510 kullanıc yorumu Google Sheets'te "DETECTLANGUAGE" fonksiyonu kullanılarak filtrelenmiş ve İngilizce dışındaki dillerde yapılmış olan yorumlar araştırmanın dışında bırakılmıştır, böylece kullanılacak olan algoritmanın etkinliği arttırılmıştır. Bu süreç sonunda 487 adet, İngilizce yazılmış kullanıcı yorumu elde edilmiştir. 


\section{4. İşlem}

Illk araştrma sorusunu cevaplamak üzere Yan ve diğerlerinin (2014) geliştirdiği yarı otomatik içerik analizi yaklaşımı kullanılmıştır. Rapidminer Studio kullanılarak k-Nearest Neighbors operatörünü merkez alan bir sınıflandırma algoritması tasarlanmıştır (Şekil 2). Bu sınıflandırma algoritmasıyla kullanıcılar tarafindan gönderilen yorumlar Nefret Söylemi, Nefret Söylemi Değil şeklinde kodlanarak yarı otomatik içerik analizi sürecinin ilk aşaması olan "insan kodlaması" safhası gerçekleştirilmiş ve algoritma için bir eğitim seti hazırlanmıştır. Eğitim seti hazırlanırken 147 yorum (toplanan yorumların yüzde 30'u) rastgele seçilerek kodlanmıştr. Eğitim seti olarak seçilen ve kodlanan yorumların yüzde $25^{\prime} \mathrm{i}$ rastgele seçilerek iletişim alanında çalışmalar yürüten başka bir araştırmacıya kontrol ettirilmiş ve eğitim setinin güvenilirliği araştırmacıların hemfikir olma yüzdesi üzerinden belirlenmiştir. Bu sürecin sonunda araştırmacıların rastgele seçilen yorumların nefret söylemi içerip içermiyor oluşunda yüzde 81 hemfikir olduğu tespit edilmiştir. Graham (2012) kodlayıcılar arasındaki minimum hemfikir olma oranının yüzde 75 olması gerektiğini ifade etmektedir. Bu yönüyle eğitim setinin algoritmayı eğitmek için kullanılabileceğini belirtmek mümkündür.

Şekil 2: Rapidminer Studio'da Tasarlanan Sınıflandırma Algoritması

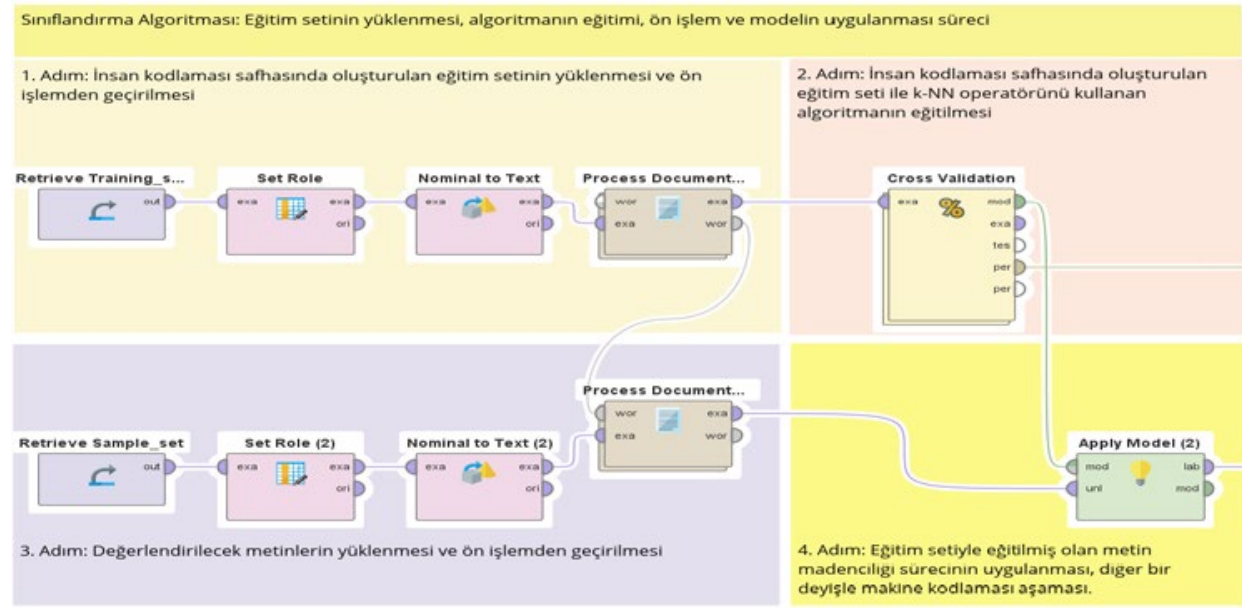

Eğitim setinin güvenirliğinden emin olunduktan sonra "makine kodlaması" aşamasına geçilmiştir. Bu aşamada sınıflandırma algoritması, insan kodlaması aşamasında oluşturulan eğitim setiyle eğitilmiş, değerlendirilecek yorumlar ve eğitim seti ön hazırlık süreçlerine tabi tutulmuştur. Ön hazırlık sürecinde cümlelerin kelimelere ayrılması, kelimelerin hepsinin küçük harfe dönüştürülmesi; and, or gibi doldurma kelimelerinin metinlerden çıkarılması; kelimelerin eklerinin dönüştürülmesi işlemleri uygulanmıştır. Ardından yorumlar sınıflandırıımıştır. 
Makine kodlamasının ardından, yarı-otomatik içerik analizi sürecinin üçüncü aşaması olan "düzeltme" kısmına geçilmiştir. Bu aşamada algoritma tarafindan sunulan referans değerlendirmeler gözden geçirilmiş, yorumların içerikleri gözden geçirilerek yorumlara algoritma tarafindan atanan değerlerde düzeltmeler gerçekleştirilmiştir.

Nefret söylemi içeren yorumlar saptandıktan sonra, çalışmanın ana amaçlarından olan Kovid-19 pandemisi sürecinde mültecilere yönelik nefret söylemindeki ana temaları belirlemek üzere kelime vektörleri geliştirilmiştir. Bu işlem hangi kelimelerin nefret söylemi içeren yorumların tümünde kaç defa geçtiğini sayılarına göre listelemek amacıyla başka bir algoritma tasarlanarak gerçekleştirilmiştir. Son olarak, yorumların tümünde en az 4 defa geçen kelimeler göz önünde bulundurularak ve yorumlar gözden geçirilerek yorumları sınıflandırmak üzere kategoriler oluşturulmuştur.

İkinci araştırma sorusu cevaplanırken kategorilere ayrılmış olan kullanıc yorumlarının almış oldukları beğeni sayıları hesaplanmış ve görselleştirilmiştir. Üçüncü araştırma sorusunu cevaplamak üzere yorumlar kategorik olarak ayrı dosyalar hâlinde kaydedilmiştir. Sonrasında her dosyada hangi kelimenin kaç defa geçtiği tespit edilmiştir (bu süreçte dolgu kelimeler çıkarılmıştır). Bir dosyada en az 2 defa tekrarlanan kelimeler göz önünde bulundurulmuş ve ardından Gephi 0.9.2 ile ağ haritası tasarlanarak hangi nefret söylemi kategorisinde hangi kelimelerin kullanıldığı belirlenmiştir. Böylece Kovid-19 salgını bağlamında mültecilere yönelik nefret söylemi içeriği taşıyan kullanıcı kaynaklı içeriklerin dilsel yansıması keşfedilmiştir.

\section{Bulgular}

Gerçekleştirilen analizler ve veri setinin incelenmesi sonucunda araştırma sorularına yönelik aşağıdaki bulgular elde edilmiştir:

A.S. 1: Kovid-19 salgını bağlamında mültecilere yönelik nefret söylemi içeriği taşıyan kullanıcı kaynaklı içeriklerin tematik dağılımı nedir?

Sınıflandırma algoritması, sınıflandırma kesinliğinin yüzde 79.86 olduğuna işaret etmiştir. Bir algoritmanın metinleri insan perspektifiyle değerlendirmesinin güçlüğü göz önünde bulundurulmak ile birlikte, algoritma tarafindan sunulan sonuçların tarafsız bir referans noktası sunmak noktasında işlevsel olduğunun altı çizilmelidir. Makine kodlamasının ardından, yarı-otomatik içerik analizi sürecinin üçüncü aşaması olan "düzeltme" uygulanmıştir.

Analiz sonucunda, veri setinde bulunan kullanıcı yorumlarının yüzde 29'unun nefret söylemi içerdiği sonucuna ulaşılmıştır. Bu noktada ilginç bir bulgunun altını çizmek önem taşımaktadır. Nefret söylemi içeren yorumlar toplam kullanıcı yorumlarının 
küçük bir bölümünü oluşturuyor olsa dahi, almış oldukları etkileşim değerlendirilen kullanıcı yorumlarına gelen toplam etkileşimin yüzde 49'unu oluşturmaktadır. Nefret söylemi olarak kategorize edilmiş yorumlarda hangi kelimelerin kaç defa geçtiği göz önünde bulundurularak takip eden kategoriler oluşturulmuştur.

- Hedef Ülkenin Dokunulmazlığı: Bu kategorideki yorumlarda mültecilerin gitmek istedikleri ülkelere yönelik vurgu yüksektir. Mültecilerin gitmek istediği ülkelere bu ülkelerin sadece vatandaşlarına ait olduğu belirtilerek kabul edilmemesi gerektiği, bu ülkelerin de çözmesi gereken sorunları olduğu ifade edilmektedir. Ayrıca, "Evinize - ülkenize dönün, buraya gelmenizi kim söyledi?" gibi yorumlar da bu kategori altında sınıflandırılmıştı.

- Amaca Yönelik Nefret Söylemi: Mültecilerin bir zorunluluk sebebiyle değil hedef ülkelerde sağlanan hizmetlerden faydalanmak için ekonomik amaçlarla veya burada başka amaçları bulunduğundan bu ülkelere ulaşmak istediği dile getirilmektedir.

- Kişisel Tercih ve Özelliklere Yönelik Nefret Söylemi: Mültecilerin dini tercihleri, cinsiyeti, yaşı, hayat tercihleri, kaynak ülkeleri ile ilgili söylemler bu kategori altında sınıflandırılmıştır.

- Diğer: Yukarıdaki kategorilerle uyumlu olmayan, çok kısa ve aynı zamanda mültecilere yönelik iyi niyet barındırmayan yorumlar bu kategori ile kodlanmıştır.

Yorumların yukarıda değinilen kategorilere uygun şekilde sınıflandırılmasının ardından Şekil 3'te görselleştirilen dağılım elde edilmiştir. Bu bağlamda, yorumların yarısının Hedef Ülkenin Dokunulmazlığı kategorisi başlığı altında değerlendirilebileceği anlaşılmaktadır.

Şekil 3: Nefret Söylemi İçeren Yorumların Kategorik Dağılımı

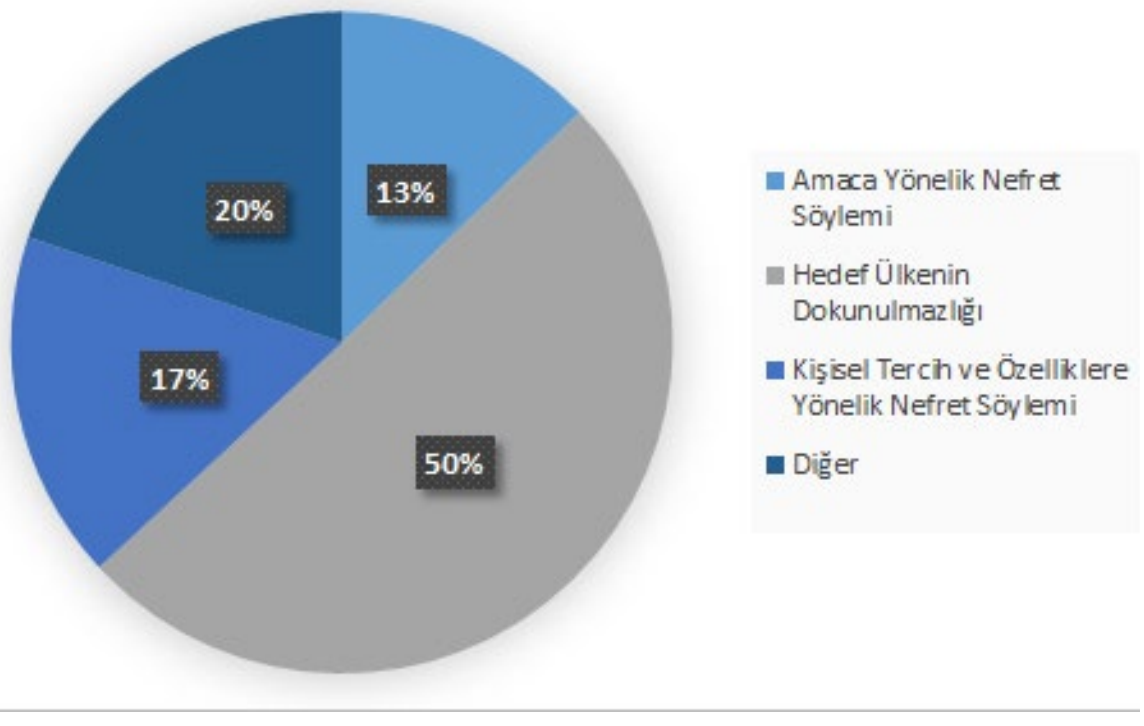


A.S. 2: Kovid-19 salgını bağlamında mültecilere yönelik nefret söylemi içeriği taşıyan kullanıcı kaynaklı içeriklerin beğeni miktarı nedir?

Hedef Ülkenin Dokunulmazlığı kategorisindeki beğeni sayısının diğer kategorilere göre daha fazla olduğu saptanmıştır. Ortalama beğeni sayısı hesaplandığında Amaca Yönelik Nefret Söylemi ve Hedef Ülkenin Dokunulmazlığı kategorilerindeki beğeni sayılarının genel ortalamadan yüksek olduğu gözlemlenmektedir.

Şekil 4: Nefret Söylemi İçeren Yorumların Kategorik Olarak Yüzdesel Beğeni Miktarı

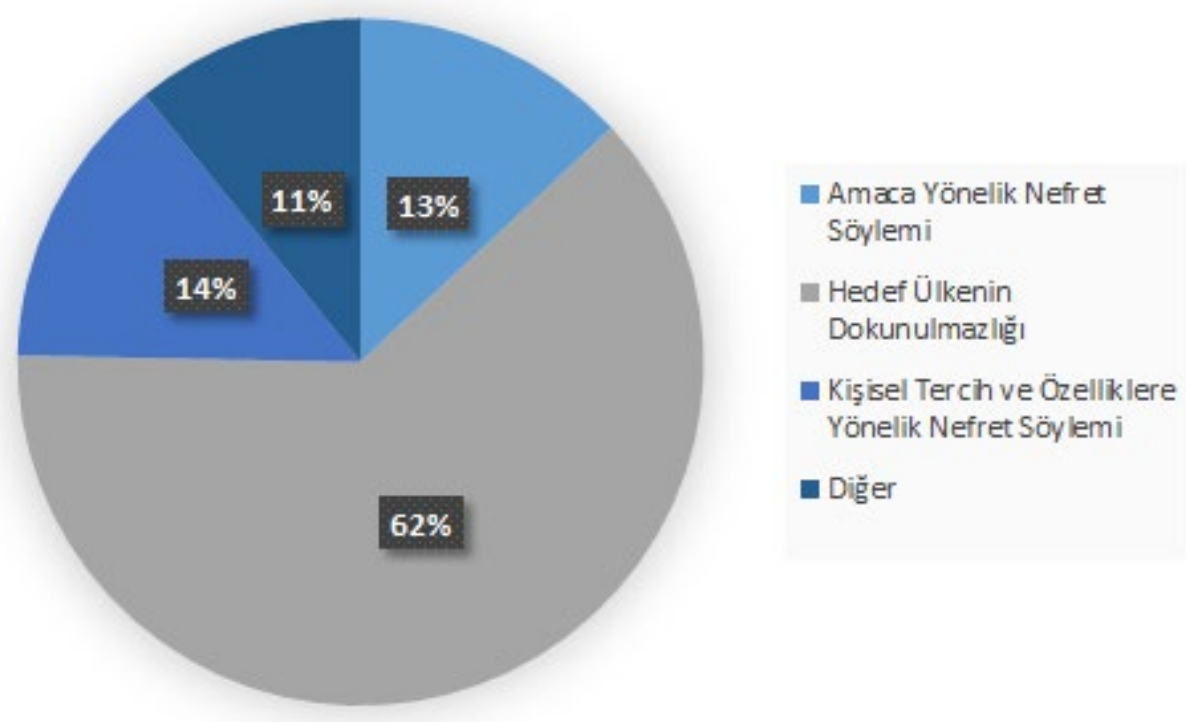

Şekil 5: Her Kategorideki Yorumların Almış Olduğu Ortalama Beğeni Sayısı

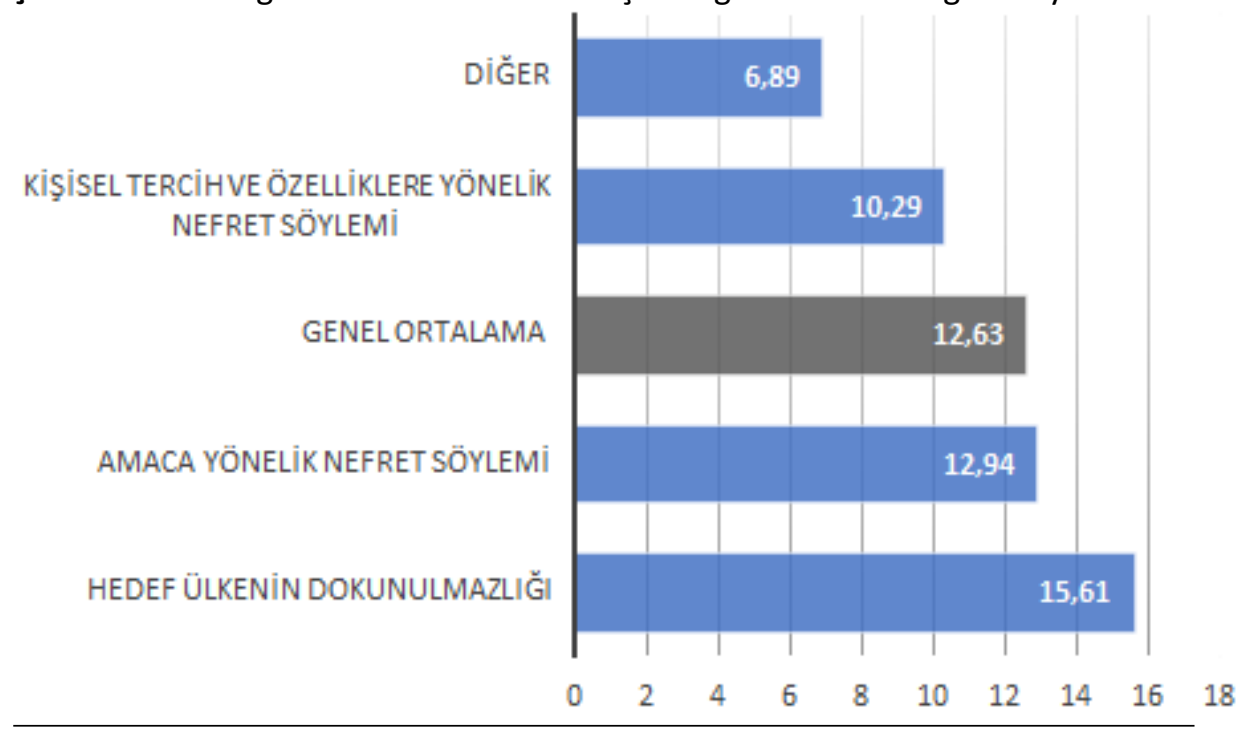


A.S. 3: Kovid-19 salgını bağlamında mültecilere yönelik nefret söylemi içeriği taşıyan kullanıcı kaynaklı içeriklerin dilsel yansıması nedir?

Bu araştırma sorusunu cevaplamak üzere Şekil 4'teki ağ haritası tasarlanmıştır. Hedef Ülkenin Dokunulmazlığı kategorisinde sıklıkla ülke ve vatandaşlık isimlerinden bahsedilmiştir. Bunun yanı sıra iş, istihdam, barınma, kaynak gibi kelimelere de bu kategorideki yorumlarda sıkça rastlanmıştır. Ayrıca güvenliğe işaret eden sınır, polis, korumak gibi kelimelerin mevcudiyeti de söz konusudur. Kişisel Tercih ve Özelliklere Yönelik Nefret Söylemi içeren yorumlarda ülke ve azınlık isimleri, İslam, garip, yasal olmayan gibi kelimeler kullanılırken; cinsiyet, yaş ve çocuk sahipliğine yönelik kelimelerin kullanıldığına da rastlanmaktadır. Amaca Yönelik Nefret Söylemi kategorisinde ücretsiz, eğitim, vergi ödeyenler, ödemek, çalışmak, ekonomi gibi kelimelerin yanı sıra ülke ve vatandaşlık isimlerinden bahsedildiği görülmektedir. Diğer kategorisinde sınıflandırılan nefret söylemindeki kelimeleri belirli bir bağlam dâhiline sınıflandırmak mümkün olmamakla birlikte diğer kategorilerle ortak şekilde kullanılan pek çok kelime içerdiğini belirtmek mümkündür.

\section{Tartışma ve Sonuç}

Öncelikle büyük veri perspektifinin sosyal bilimler çalışmalarındaki potansiyel katkısına ışık tutabilmek adına çalışma kapsamında kullanılan veri seti ve yenilikçi yöntem öncül çalışmalar bağlamında tartışılmalıdır. Çalışma kapsamında ulaşılan verinin büyüklüğü teknik boyutlarıyla ele alındığında büyük veri şeklinde tanımlanamayacak olsa dahi büyük verinin düşünsel yönünü temsil eden özelliklere sahiptir. Mevcut veri seti Stephens-Davidowitz'in (2018) ifade etmiş olduğu güçlü yönleri yansıtan kimi bileşenlere sahiptir. Verinin kullanıcıların samimi görüşlerini içerdiği ve farklı neden-sonuç ilişkileri kurmaya olanak tanıdığı düşünülmektedir. Çalışma kapsamında değerlendirilen verinin Bruns'ın (2012) fikirleriyle de örtüştüğü görülmektedir. YouTube platformundan toplanan verinin, sosyal ağlardaki tartş̧malara benzer bir şekilde, erişilebilir ve zengin olduğunu dile getirmek mümkündür.

Ayrıca verinin analiz süreçlerinde, sosyal bilimlerde büyük ölçekli veriler analiz edilirken başvurulan yöntemlerden faydalanılmış ve kesinliği yüksek sonuçlar elde edilmiştir. Çalışmada kullanılan yöntem, Akdeniz'in (akt. Sütcü ve Aytekin, 2018: 81) betimlemiş olduğu veri bilimi aşamalarıyla da örtüşen bir özellik taşımaktadır. Çalışma kapsamında araştırma soruları tanımlanmış, veri Facepager (Jünger ve Keyling, 2020) aracı ile elde edilmiş, Google Sheets'in de dâhil edildiği bir süreçle ayıklanmış, k-NN temelli bir algoritmanın da dâhil olduğu istatistiksel bir temelde yarı otomatize bir yaklaşımla değerlendirilmiş, benzer bir tekniğin 
tekrar uygulanabilirliğini arttırmak için çalışmanın aşamaları anlaşılabilir bir şekilde aktarılmıştır. Çalışmada kullanılan yaklaşım ve verinin doğası, sosyal bilimler alanında büyük ölçekli verileri yenilikçi yöntemlerle analiz eden diğer çalışmalara benzer bir şekilde, kullanıc kaynaklı içerikteki örüntüleri belirlemeyi olanaklı kılmıştır.

Çalışma kapsamında nefret söylemi olarak değerlendirilen kullanıcı yorumları Parekh (2006) ve Weber (2009) tarafindan öne sürülmüş olan nefret söylemi tanımları çerçevesinde belirtilen bileşenlerden birini veya mültecilere yönelik saldırgan söylemleri içermektedir. Kovid-19 bağlamında mültecilerle ilgili haber videoları altına kullanıcılar tarafindan yazılmış yorumlarda düşmanlık, reddediş, saldırgan ulusalcılık veya şartlar ne olursa olsun kaderine razı olma durumunun dayatılması söz konusudur. Bulgular, yorumlar aracılığı ile dile getirilen doğrudan nefret söyleminin yanı sıra dolaylı nefret söyleminin yaygınlığına da işaret etmektedir. Çünkü nefret söylemi içeren yorumlar veri setinin yüzde $29^{\prime}$ luk bir bölümünü oluşturuyor olsa dahi toplam etkileşimin yüzde 49'unu oluşturmaktadır. Bu durum, nefret söylemi içeren kullanıcı yorumlarının daha görünür olma ihtimali taşıdığına işaret etmektedir. Bu noktada Ziems ve diğerlerinin (2020) bulguları hatırlanmalıdır. Araştırmacılar, nefret içeriğine maruz kalan bir bileşenin, sonrasında nefret dolu olma eğilimi gösterdiğine işaret etmektedir. Bu durum çalışmanın bulguları ışı̆ında değerlendirildiğinde, yüksek beğeni alan ve görünür olma potansiyeli artan nefret içerikli kullanıcı yorumlarının başka kullanıcıları da etkileme ihtimali olduğunu belirtmek mümkündür. Bu durumda mültecileri Kovid-19 salgını sürecinde kırılgan hâle getiren bir dijital nefreti söylemi döngüsünden de bahsetmek mümkün olacaktır.

Mevcut bulgular göstermektedir ki mültecilere yönelik süregelen nefret söylemi örüntüleri Kovid-19 salgını sürecinde de devam etmektedir. Özellikle Hedef Ülkenin Dokunulmazlığı ve Amaca Yönelik Nefret Söylemi içeren yorumlarda bu duruma rastlamak mümkündür. Bu iki kategorideki kullanıcı yorumlarının içeriğinde geçmişte farklı bağlamlarda mültecilere yönelik ifade edilen nefret söylemindeki ifadelerle benzerlik dikkat çekicidir. Diğer yandan, geçmiştekine benzer bir şekilde, mültecilerin bir güvenlik tehlikesi gibi görülmesine yorumlarda rastlanmamıştır.

Hedef Ülkenin Dokunulmazlığı kategorisindeki yorumlar mültecilerin bulundukları ülkeden doğrudan çıkarılmasını talep etmektedir. Bu talepler dile getirilirken mültecilerin kaynak ülkelerindeki kötü şartların göz önünde bulundurulmadığı ve "hızlıca kurtulma" refleksinin söz konusu olduğu dikkat çekmektedir. Bu bağlamda dikotomik bir dünya görüşünün var olduğunun da altı çizilmelidir. Çünkü bu 
kategorideki kimi yorumlarda Avrupa'nın Avrupalılara ait olduğu vurgulanmaktadır veya mültecilerin zengin Müslüman ülkelere gönderilmesi çağrısında bulunulmaktadır. Diğer yandan, sağlanan mevcut yardımlarla yetinilmesi gerektiği veya hedef ülkelerde de işsizlik gibi sorunlarının olduğu belirtilmektedir. Mevcut bulgular ışığında farklı bağlamlarda geçmişte de rastlanılan mülteci karşıtı söylemin, Kovid-19 salgını sürecinde de benzer şekilde devam ettiği görülmektedir. Yorumlar Kovid-19 ve mültecilerle ilgili haber videolarının altına yazılıyor olsa dahi, yorumlarda Kovid-19'la bağlantılı kelimeler içeren nefret söylemine seyrek şekilde rastlanmaktadır. Hedef Ülkenin Dokunulmazlığı kategorisindeki yorumlarda Kovid, corona, pandemic gibi kelimelerin 71 yorumdan sadece 4 tanesinde tespit edilmesi de bu durumu destekler niteliktedir.

Amaca Yönelik Nefret Söylemi kategorisindeki yorumlarda ise mültecilerin ülkelerindeki zor şartlar yerine farklı amaçlarla göç ettiklerine değinilmektedir. Bu kategorideki yorumlarda mültecilerin ekonomik amaçları olduğu, hedef ülke vatandaşlarından daha iyi bir hayat sürdükleri, ücretsiz destek almak için hedef ülkelere göç ettikleri dile getirilmektedir. Bu durum, mültecilerin çıkarları uğrunda hareket ettikleri yönünde bir algı oluşturma potansiyeli taşımaktadır. Bu durumun mültecilere yönelik sosyal destek ve hoşgörünün azalmasına sebep olabileceği yorumunu yapmak mümkündür. Dolayısıyla uzun vadede mültecilerin sosyal entegrasyonu sürecini etkileme potansiyeli taşımaktadır.

Kişisel Tercih ve Özelliklere Yönelik Nefret Söylemi kategorisindeki yorumlarda mültecilerin dini tercihlerine yönelik saldırgan ifadeler bulunmaktadır. Bu kategorideki yorumlarda mültecilerin yaşlarının genç olduğu vurgulanmaktadır. Bu tipteki yorumlar önceki kategorilerdeki yorumlar ışığında değerlendirildiğinde, mültecilerin yardıma ihtiyacı olmadığı veya mültecilerin dini tercihlerinin dikotomik bir perspektiften değerlendirilerek ötekileştirildiği yorumunu yapmak mümkün hâle gelmektedir. Ayrıca, bu kategorideki kullanıcı yorumlarında mültecilerin çocuk sahibi olma tercihlerine yönelik ifadelere de rastlanmıştır.

YouTube'da Kovid-19 ve mültecileri ele alan haber videolarına yazılmış kullanıcı yorumları analiz edilerek erişilen sonuçlar mültecilere yönelik nefret söyleminin boyutlarını ve bir yönüyle de arkasındaki sebepleri anlamaya imkân tanımıştır. Görülmektedir ki Kovid-19 salgını sürecinde mültecilere karşı dile getirilen dijital nefret söylemi kökünü geçmişte rastlanılan nefret söyleminden almakta ve geçmişteki nefret söylemi örüntüleri ile benzerlik göstermektedir. Bu söylemle mücadele etmek üzere dijital platformların, toplumsal katılımı da göz önünde bulundurarak etkin nefret söylemi ile mücadele politikaları geliştirmesi önem taşımaktadır. Diğer yandan, dijital medya okuryazarlığı eğitimine önem verilmesi 
ve bu süreçte kültürlerarası iletişim gibi konulara da değinilmesi herkesin içerik üreticisine dönüştüğü ve başkalarını etkileme imkânına kavuştuğu bir dünyada önem taşımaktadır.

Bu çalışmanın uygulamaya yönelik çıktılarının da olduğunu belirtmek mümkündür. Çalışma, büyük ölçekli verilerin analizinde gelecek çalışmalarda da kullanılabilecek, metin madenciliği temelli çerçeve bir süreç sunmaktadır. Fakat ele alınan veriler ve bulgular, belirtilmiş olan YouTube videolarından toplanan kullanıcı yorumları ile sınırlıdır. Gelecek çalışmalarda, bu sürecin daha büyük veri setleri ile gerçekleştirilmesi ve platformlararası karşılaştırmalar yapılması Kovid-19 salgını sürecinde mültecilere yönelik nefret söyleminin çok boyutlu bir şekilde anlaşılmasına ve dijital nefret söyleminin önlenebilmesine yardım edecektir.

\section{Kaynakça}

Akgül, M. Çevrim içi Ortamlarda Nefret Söylemi: Ekşi Sözlük'te 65 Yaş Üstü Sokağa Çıkma Yasağı Tartı̧̧maları. İletişim Kuram ve Araştırma Dergisi, 2020 (51), 57-78.

Arcila Calderón, C., Blanco-Herrero, D., \& Valdez Apolo, M. B. (2020). Rejection and Hate Speech in Twitter: Content Analysis of Tweets about Migrants and Refugees in Spanish. Revista Española de Investigaciones Sociológicas, 172, 21-40.

Awal, M. R., Cao, R., Mitrovic, S., \& Lee, R. K. W. (2020). On analyzing antisocial behaviors amid covid-19 pandemic. arXiv preprint arXiv:2007.10712.

Binark, M. (2010). Nefret Söyleminin Yeni Medya Ortamında Dolaşıma Girmesi ve Türetilmesi. In T. Çomu (Ed.), Yeni Medyada Nefret Söylemi (11-53). İstanbul: Kalkedon.

Bruns, A. (2012). "How Long is a Tweet? Mapping Dynamic Conversation Networks on Twitter Using Gawk and Gephi", Information, Communication \& Society, 15:9, 1323-1351, DOI: 10.1080/1369118X.2011.635214

Chaudhry, I. (2015). \#Hashtagging hate: Using Twitter to track racism online. First Monday, 20(2). https://doi.org/10.5210/fm.v20i2.5450

Chi, C. (2020). Unstructured Data Vs. Structured Data: A 3-Minute Rundown. https://blog. hubspot.com/marketing/unstructured-data adresinden alındı

Cox, M., Ellsworth, D. (1997). Application-Controlled Demand Paging for Out-of-Core Visualization.

Desjardins, J. (2019). How much data is generated each day?. https://www.weforum.org/ agenda/2019/04/how-much-data-is-generated-each-day-cf4bddf29f adresinden alındı.

Eaton, C., Deutsch, T., Deroos, D., Lapis, G. P. Z. (2012). Understanding Big Data: Analytics for Enterprisse Class Hadoop and Streaming Data. USA: McGraw-Hill.

Fasel, D. (2014). Big Data - Eine Einführung. HMD Praxis Der Wirtschaftsinformatik. https://doi.org/10.1365/s40702-014-0054-8

Graham, M., Milanowski, A., \& Miller, J. (2012), Measuring and Promoting Inter-Rater Agreement of Teacher and Principal Performance Ratings. Center for Educator Compensation and Reform. 
Guadagno, L. (2020). Migrants and the COVID-19 pandemic: An initial analysis. International Organization for Migration, Migration Research Series, (60).

Hammad, K. A. I., Fakharaldien, M., Zain, J., \& Majid, M. (2015, September). Big data analysis and storage. In International Conference on Operations Excellence and Service Engineering (pp. 10-11).

Jaki, S., \& De Smedt, T. (2019). Right-wing German hate speech on Twitter: Analysis and automatic detection. arXiv preprint arXiv:1910.07518.

Jünger, J. \& Keyling, T. (2020). Facepager. An application for automated data retrieval on the web. Source code and releases available at https://github.com/strohne/Facepager/.

Kuş, O. (2016). Dijital Nefret Söylemini Anlamak: Suriyeli Mülteci Krizi Örnek Olayı Bağlamında BBC World Service Facebook Sayfasına Gelen Yorumların Metin Madenciliği Tekniği ile Analizi. İstanbul Üniversitesi İletişim Fakültesi Dergisi | Istanbul University Faculty of Communication Journal , (51) , 97-121 . DOI: 10.17064/iuifd.289373

Meciar, M. (2020). Koronavirüs Salgınında Göçmenlere Yönelik Medya Söylemi: Türk ve Çek Yazılı Çevrim içi Medya Karşılaştırması. Göç Dergisi, 7(2), 189-209. https://doi.org/10.33182/gd.v7i2.713

Michael A. Peters (2020) Limiting the capacity for hate: Hate speech, hate groups and the philosophy of hate, Educational Philosophy and Theory, DOI: 10.1080/00131857.2020.1802818

Musto, C., Semeraro, G., de Gemmis, M., \& Lops, P. (2016, July). Modeling community behavior through semantic analysis of social data: The italian hate map experience. In Proceedings of the 2016 Conference on User Modeling Adaptation and Personalization (pp. 307-308).

Narin, B., Ayaz, B., Fırat, F., \& Fırat, D. (2017). Büyük Veri ve Gazetecilik İlişkisi Bağlamında Veri Gazeteciliği. AJIT-e: Online AcademicJournal of Information Technology, Vol:8, Num: 30, 215-235.

Panneerselvam, J., Liu, L., \& Hill, R. (2015). Chapter 1 - An Introduction to Big Data. In Application of Big Data for National Security (pp. 3-13). Elsevier Inc.. https:// doi.org/10.1016/B978-0-12-801967-2.00001-X

Parekh, B. (2006). Hate speech: Is there a case for banning? Public Policy Research, 12(4), 213-223.

Pariser, E. (2011). The Filter Bubble What The Internet Is Hiding From You. New York: Penguin Press.

Stephens-Davidowitz, S. (2018). Bana Yalan Söylediler: İnternet ve Gerçek Yüzümüz. İstanbul: Koç Üniversitesi Yayınları.

Sütcü, C., \& Aytekin, Ç. (2018). Veri Bilimi. İstanbul: Paloma.

Tuna Uysal, M., Tan Eren, G. (2020). COVID-19 salgın sürecinde sosyal medyada yaşlılara yönelik ayrımcılık: Twitter örneği. Turkish Studies, 15 (4), 1147-1162. https://dx.doi.org/10.7827/TurkishStudies.44396

Tunçer, Ç. Sosyal Medya ve Şiddet: Ekşi Sözlük'te Çinli Algısı. İnsan ve İnsan, 7 (25), 65-84. Türk, A. Koronavirüs (COVID-19) Pandemisi Sürecinde Yaşlılara Yönelik Uygulamalar ve YaşIıların Psiko-Sosyal Durumu Üzerine Bir Değerlendirme. Sosyal Hizmet, 35.

Weber, A. (2009). Nefret Söylemi El Kitabı. Strazburg: Avrupa Konseyi Yayınları. 
Witten, I. H. (2005). "Text Mining," The Practical Handbook of Internet Computing ed. Munindar P. Singh, Florida: Chapman \& Hâll

Yan, J. L. S. McCracken, N. ve Crowston, K. (2014). Semi-Automatic Content Analysis of Qualitative Data. In iConference 2014 Proceedings (p. 1128-1132)

Yun Shin, S. (2020). Study on Hate Speech against Refugees in Korea through Text Mining Analysis on Comments to Online News Articles. Yüksek Lisans Tezi. https:// dspace.ewha.ac.kr/handle/2015.oak/253172

Ziems, C., He, B., Soni, S., \& Kumar, S. (2020). Racism is a Virus: Anti-Asian Hate and Counterhate in Social Media during the COVID-19 Crisis. arXiv preprint arXiv:2005.12423. 
Ekler

Şekil 6: Kullanıcı kaynaklı içeriklerin dilsel yansımasını aktarmaya yönelik ağ haritası

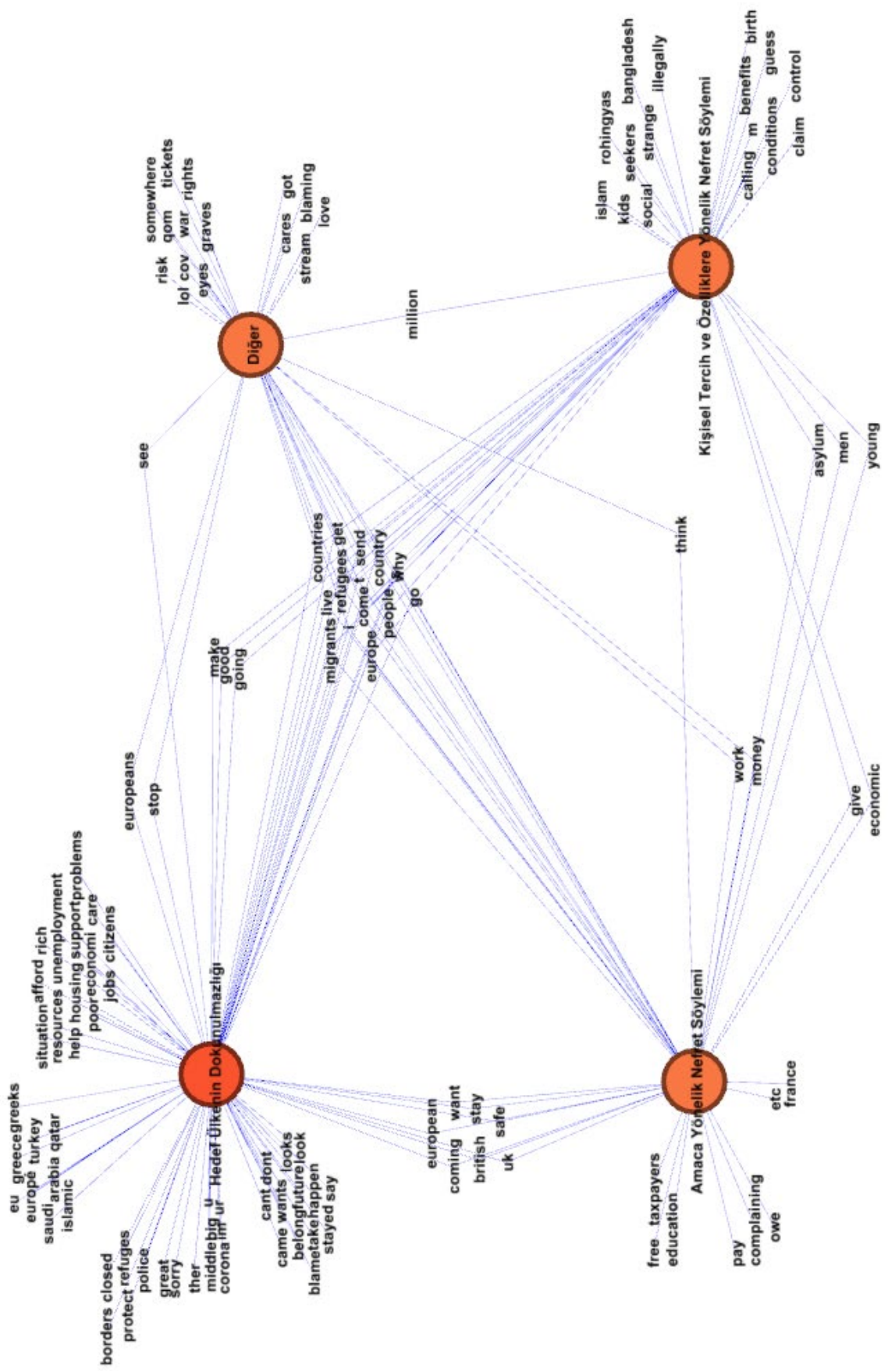

